Produto \& Produção, vol. 11, n. 3, p. 19-28, out. 2010

\title{
P P
}

\section{The moderating effects of innovativeness on new product development ability}

\author{
Marcelo Gattermann Perin \\ PPGAd - PUCRS \\ mperin@pucrs.br
}

\author{
Cláudio Hoffmann Sampaio \\ PPGAd-PUCRS \\ csampaio@pucrs.br
}

Marcia Dutra De Barcellos

$P P G A-U F R G S$

mdutrab@gmail.com

Jens Oliver Kügler

Aarhus University

jensk@asb.dk

\begin{abstract}
Apesar do número de publicações específicas sobre Orientação para Aprendizagem e para Mercado, não há consenso sobre a relação entre estes construtos e Inovação (IN). Neste sentido, este estudo investiga o impacto da Orientação para Aprendizagem e para Mercado na Habilidade de Desenvolvimento de Novos Produtos (HDNP) em contextos de alta e baixa orientação para Inovação. A população alvo foi um grupo de empresas brasileiras com mais de 30 empregados. Os dados foram analisados através de uma análise de regressão hierárquica. Os resultados indicam um impacto significativo e negativo da interação Orientação para Mercado x Capacidade de Inovação na HDNP. Já a interação Orientação para Aprendizado x Capacidade de Inovação apresentou um efeito significativo e positivo sobre HDNP. Portanto, em ambientes de negócios com alto nível Inovação, a Orientação para Aprendizagem excede a importância da Orientação para Mercado no desenvolvimento de novos produtos. Quando o nível de Inovação das empresas é baixa, porém, a HDNP tende a tirar proveito da Orientação para Mercado, em vez de Orientação para Aprendizagem.
\end{abstract}

Palavras-chave: Orientação para Mercado; Orientação para Aprendizagem; Desenvolvimento de Novos Produtos.

Despite the number of specific publications on Learning and Market Orientation, there is no consensus on the relationship between these constructs and Innovation. In this sense, this study investigates the impact of Learning and Market Orientation in the firm's New Product Development Ability (NPDA) in high and low innovativeness contexts. The target population was a group of Brazilian firms with more than 30 employees. The data was analysed through a hierarchical regression analysis. The results indicate a significant and negative impact of Market Orientation x Innovativeness interaction in the NPDA capacity. On the other hand, Learning Orientation x Innovativeness interaction presented a significant and positive effect on NPDA. Thus, Learning Orientation exceeds the importance of Market Orientation in the development of new products in business environments with high Innovativeness level. When the firms' Innovativeness level is low, however, the NPDA capacity tends to take advantage from Market Orientation rather than Learning Orientation.

Keywords: Market Orientation; Learning Orientation; New Product Development.

\section{Introduction}

According to original studies of Narver and Slater (1990) and Kohli and Jaworski (1990), research on market orientation and its relationship with business performance has been a quite productive field of study within the scope of marketing literature worldwide
(Lafferty and Hult, 2001). In Brazil, Perin and Sampaio have investigated this issue extensively (see Vieira, 2010). Most studies indicate that Market Orientation has been pointed as positively correlated with performance (Hunt and Morgan, 1995) and innovation (Theoharakis and Hooley, 2008). 
Several empirical studies investigate the impact of learning orientation and Market Orientation on innovation (Slater and Narver, 1995; Hurley and Hult, 1998; Baker and Sinkula, 1999; Farrell, 2000; Lukas and Ferrel, 2000; Slater and Narver, 2000; Baker and Sinkula, 2007), aiming at understanding how firms maintain sustainable competitive advantages in their target markets.

Interestingly, some authors agree that Market Orientation is necessary but not enough to maintain competitive advantages in the long run (Slater and Narver, 1995; Dickson, 1996; Lukas and Ferrell, 2000). Day (1994) sustains that the ability to engage in organizational learning process must follow Market Orientation to assure sustainable competitive advantages to the firm. Learning Orientation and Market Orientation could therefore possibly increase the firm's new product development ability (i.e., to increase the "ability of the organization to adopt or implement new ideas, processes, or products successfully") (Hurley and Hult, 1998:44).

In spite of the relationships among Market Orientation and Learning Orientation with business performance, there are indicatives that these effects can be moderated by other constructs (Hooley et al., 2001), as the level of innovativeness (Augusto and Coelho, 2009; Menguc and Auh, 2006), for instance. The empiric impact of such marketing resources, however, are still incipient (Hooley, Greenley, Cadogan, and Fahy, 2005), especially in emerging markets (Iyer, Laplaca and Sharma, 2006).

Previous studies indicate that Market Orientation and Learning Orientation are key antecedents of the new product development success, although some controversial results suggest potential moderators and mediators of those relationships (e.g., Lukas and Ferrell, 2000, Mavondo, Chimhanzi and Stewart, 2005; Wei and Atuahene-Gima, 2009), emphasising the lack of empirical corroboration of the relationship among Market Orientation, Learning Orientation and New Product development Ability in distinct Innovativeness contexts (Augusto and Coelho, 2009; Menguc and Auh, 2006), particularly in developing countries (Rhee, Park and Lee, 2010). In this sense, this study investigates the impact of Learning Orientation and Market Orientation in the firm's New Product development Ability in high and low Innovativeness contexts in Brazil.

\section{Background and conceptual model}

Market Orientation has been posed as a central theme in Strategy and Marketing areas (Lafferty and Hult, 2001). Permanent changes in the competitive environment provide the basis for a priority status to be given to the market in contemporary businesses (Neill and Rose, 2006), especially regarding the impact of Market Orientation on companies' innovation (Menguc, and Auh, 2006). Nevertheless, distinct forms of Market Orientation based on different emphases on several dimensions of that construct have been left unaddressed by academic studies.

Baker and Sinkula (2005) postulate that the success of new products is directly influenced by the Market Orientation level of the firm. This concept is consistent with other formulations (Atuahene-Gima, 1996; Han, Kim and Srivastava, 1998) and supported by previous studies (Baker and Sinkula, 1999). Market-oriented companies are more prone to develop new products that can offer distinguished benefits to the consumer, as well as superior quality in relation to competitors' products (Jaworsky and Kohli, 1993).

According to Hooley et al. (2005), Market Orientation increasing also enables the development of relationships with customers (Day, 1994) and increases the ability to develop and launch new products and services. Such ability is known as New Product Development Ability (Slater and Narver, 1995; Han et al., 1998).

Considering that market-oriented firms are more qualified to identify and assist consumers' latent needs, they have larger probability to be the first in the market with a new generation of existing products and services (Narver and Slater, 1990; Baker and Sinkula, 2005).

A successful innovation, as mentioned above, requires the development of abilities and resources in a singular way (Hooley et al., 2005) by extrapolating the stock of existent market knowledge. In line with this discussion, a consistent theoretical body investigates whether Market Orientation facilitates or obstructs the success of New Product Development Ability (e.g., Lukas and Ferrell, 2000; Gotteland and Boule, 2006). Therefore, we hypothesise that:

\section{H1 - Market Orientation has a positive impact on the New Product development Ability}

Christensen and Bower (1996) and Chandy and Tellis (2000) sustain that Market Orientation limits firms to customer-led incremental innovation activities, particularly in contexts of low level of Innovativeness (Baker and Sinkula, 2005). This stream reinforces the interference of mediators and moderators in the relationship between Market Orientation and innovation issues (Mavondo, Chimhanzi and Stewart, 2005; Wei and Atuahene-Gima, 2009). Hence, in spite of the theoretical background suggesting that there is a positive interaction between Market Orientation and Innovativeness on firm performance, this article is aligned with 
a theoretical view where Market Orientation is believed to be important but not enough to modify the current mental models and to promote the innovation based on new paradigms besides those already identified in the environment (Woodside, 2004; Atuahene-Gima, 2005; Neill and Rose, 2006). In that way, Market Orientation has an essential role in more stable environments and in low Innovativeness contexts since it allows firms to identify, disseminate and answer market demands. Further, Market Orientation would not be enough to break with traditional models and to stimulate radical innovation in more turbulent environments characterized by high Innovativeness (Baker and Sinkula, 2005; Baker and Sinkula, 2007). Thereafter:

H2 - The impact of Market Orientation on the New Product development Ability is negatively moderated by the Innovativeness level.

Acknowledging the growing popularity of organizational learning within firms, there is little consensus in terms of its definition, operation and methodology (Rebelo and Gomes, 2008). This lack of convergence is partially due to the fact that distinct investigators have applied the concept or terminology of learning within the firm to multiple fields (Crossan, Lane and White, 1999). Hence, several authors in the Marketing area have agreed that organizations must engage themselves in organizational learning processes to reach long-term competitive advantage by encouraging Innovativeness, particularly within dynamic and competitive environments (e.g., Atuahene-Gima, Slater, and Olson, 2005; Baker and Sinkula, 2005; Baker and Sinkula, 2007; Rhee et al., 2010), suggesting that Learning Orientation is directly associated to New Product Development Ability (Calantone, Cavusgil, and Zhao, 2002; Hult, Hurley, and Knight, 2004). Consequently:

\section{H3 - Learning Orientation has a positive impact on the New Product development Ability.}

In this sense, Learning Orientation has been recognized as strongly associated to Innovativeness (Rhee et al., 2010). According to Baker and Sinkula (1999: 413), Learning Orientation is "a set of values that influence the degree to which a firm is satisfied with its theories in use". Therefore, companies with a high level of Learning Orientation encourage or even demand from staff a permanent challenge that guides their market information processing and organizational actions (Hult et al., 2004). Thus, Learning Orientation directly affects the ability to challenge old assertions or "truths" about the market and indicates how the company should be organized to promote innovation based on new paradigms (Baker and Sinkula, 2007).

Mavondo, Chimhanzi and Stewart (2005) also associate Learning Orientation to performance and indicate that firms with high levels of Learning Orientation outperform their rivals, particularly in turbulent, intensely competitive environments characterized by high Innovativeness contexts (McGuinness and Morgan 2005). Such outcome can be explained by a higher capacity on understanding and effectively satisfying their needs through new products and ways of doing business (Slater and Narver, 1995). However, the distinctive effects of Learning Orientation are not expected to be apparent in low Innovativeness contexts (Baker and Sinkula, 2007; Rhee et al., 2010). The main contribution of Learning Orientation to the New Product development Ability is changing theories-in-use, mental models and dominant logics, what leads to radical innovation - a characteristic not common in low Innovativeness contexts (Mavondo et al.,2005). Thus:

H4 - The impact of Learning Orientation on the New Product development Ability is positively moderated by the Innovativeness level.

\section{Method}

\subsection{Data collection procedure and sampling}

In the present study, a group of Brazilian firms with more than 30 employees was defined as target population. These firms are located in different regions of the country. Similarly to other studies on the topic (e.g. Jaworski and Kohli 1993; Sinkula et al. 1997; Baker and Sinkula, 2007), our research was designed to cover a wide range of industries.

The questionnaire was originally written in English and further translated to Portuguese by a back-translation procedure (Dillon, Madden, and Firtle, 1994). The structured questionnaire was sent by mail to Chief Executive Officers (CEOs) of 3,000 companies from different industries in Brazil. 285 valid questionnaires were obtained, yielding a response rate of $9.5 \%$. This result represents an acceptable response rate (Menon et al., 1996) and is considerably higher than the response rate obtained by other studies conducted in developing countries (for example, Zou et al., 1997).

In order to control non-response bias, we have tested for possible differences on early and late received questionnaires (Armstrong and Overton 1977). The t-test for early and late respondents across all variables in the questionnaire indicates no significant differences between these two groups.

We also paid particular attention to the identification of the most appropriate person to fill out the questionnaire. To ensure reliability of the gathered data, we have selected CEOs who had direct responsibility in firms' decision-making process. 


\subsection{Measures}

The constructs used in this research were developed based on existing literature, as in Hooley et al. (2005). The construct Market Orientation was based on Narver and Slater's (1990) proposition and applied with a 7-point Likert scale. Learning Orientation was conceptualized according to the definition of Sinkula et al. (1997) with a 5-point Likert scale. New Product Development Ability was formed from the propositions of Hooley, Möller and Broderick (1998) and Day (1994), using a 5-point Likert scale. Finally, Innovati- veness was measured as the firm's tendency to initiate new procedures or systems and to engage in more innovative processes in order to achieve its targets and objectives (West and Anderson, 2003), using a 5-point Likert scale. We have also included the environment conditions (e.g., competition level and technological changes in the industry) as control variables. Previous research has shown that these variables have an impact on New Product Development Ability (Atuahene-Gima, 2005). Both variables were measured with a 5-point Likert scale. Table 1 depicts the reliability and validity of the measures.

Table 1 - Reliability and validity of measures

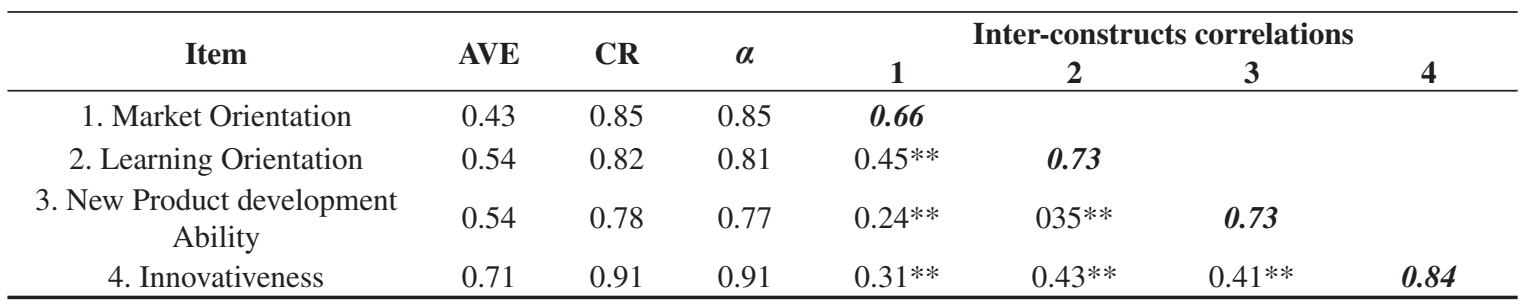

Note: Diagonal elements (in bold) are the square root of the Average Variance Extracted (AVE).

$* * \mathrm{p}<0.01$

For testing for convergent validity, a confirmatory factor analysis (CFA) on the measurement model was conducted. The model fit indices were considered highly acceptable $\left(\mathrm{X}^{2}=327.218, \mathrm{df}=145, \mathrm{X}^{2} / \mathrm{df}=2.257\right.$,
RMSEA $=0.067$, SRMR $=0.062$, TLI $=0.915$, and $\mathrm{CFI}=0.928)$.

Table 2 provides the mean, standard deviation, factor loadings and t-values for all the constructs that were

Table 2 - Mean, standard deviation, factor loadings and t-values

\begin{tabular}{|c|c|c|c|c|}
\hline Item & Mean & S.D & Loading & t value \\
\hline \multicolumn{5}{|l|}{ Market Orientation } \\
\hline Our objectives and strategies are driven by the creation of customer satisfaction & 5.81 & 1.08 & 0.65 & - \\
\hline Competitive strategies are based on understanding customer needs & 5.56 & 1.20 & 0.81 & 10.96 \\
\hline Business functions are integrated to serve market needs & 5.46 & 1.15 & 0.73 & 10.21 \\
\hline Business strategies are driven by increasing value for customers & 5.41 & 1.22 & 0.66 & 9.44 \\
\hline Customer satisfaction is systematically and frequently assessed & 5.45 & 1.47 & 0.56 & 8.14 \\
\hline Close attention is given to after sales service & 5.17 & 1.62 & 0.54 & 7.90 \\
\hline Top management regularly discuss competitors' strengths and weaknesses & 5.00 & 1.50 & 0.55 & 8.05 \\
\hline Our managers understand how employees can contribute to value for customers & 5.32 & 1.35 & 0.67 & 9.51 \\
\hline $\begin{array}{c}\text { Learning Orientation } \\
\text { Managers agree that our company's ability to learn is the key to competitive } \\
\text { advantage }\end{array}$ & 4.11 & 0.84 & 0.61 & - \\
\hline Employee training and learning is seen as an investment rather than an expense & 4.27 & 0.83 & 0.77 & 9.89 \\
\hline The underlying values of our company include learning as a key to improvement & 4.28 & 0.80 & 0.87 & 10.48 \\
\hline $\begin{array}{c}\text { Our staff realise that our perceptions of the marketplace must be continually } \\
\text { questioned }\end{array}$ & 3.60 & 0.94 & 0.66 & 8.90 \\
\hline \multicolumn{5}{|l|}{ New Product Development Ability } \\
\hline Effective new product/service development processes & 3.45 & 0.86 & 0.75 & - \\
\hline Ability to launch successful new products & 3.47 & 1.01 & 0.78 & 10.70 \\
\hline $\begin{array}{c}\text { We actively develop new products and services to lead the market } \\
\text { Innovativeness }\end{array}$ & 3.74 & 1.02 & 0.68 & 9.91 \\
\hline $\begin{array}{l}\text { (We are more innovative than our competitors in...) } \\
\ldots \text { deciding what methods to use in achieving our targets and objectives }\end{array}$ & 3.86 & 0.86 & 0.86 & - \\
\hline$\ldots$ initiating new procedures or systems & 3.83 & 0.87 & 0.87 & 18.93 \\
\hline ... developing new ways of achieving our targets and objectives & 3.83 & 0.84 & 0.89 & 19.63 \\
\hline ... initiating changes in the job contents and work methods of our staff & 3.71 & 0.86 & 0.73 & 14.29 \\
\hline
\end{tabular}


investigated. The loadings of all items on each construct were found highly significant $(\mathrm{p}<0.001)$ and exceeded the threshold value of 0.4 suggested by Hulland (1999). The high Alpha coefficients, average extracted variance and construct reliability scores for each construct were supportive of unidimensionality. Factor loadings, t-values, and composite reliability expressed high levels of item and convergent validity. To assess discriminant validity, we contrasted the correlation of each pair of factors with the squared root variance extracted from each factor (Fornell and Larcker, 1981). In each case, the average variance exceeded the squared correlation, what supported discriminant validity. Thus, we found evidence of unidimensionality, convergent validity, discriminant validity, and measurement invariance on the measurement model. All constructs were averaged for subsequent tests.

\section{Results}

We tested the hypothesised relationships by using hierarchical regression analysis. The interaction terms were created by using mean centred independent variables to reduce multicollinearity (Aiken and West, 1991). The results are reported in Table 3.

Model 1 depicts the control and the main effects. Model 2 includes the interaction terms Market Orientation x Innovativeness and Learning Orientation x Innovativeness. The second model explained $23.7 \%$ of the dependent variable - New Product development Ability and added $2.4 \%$ to its explained variance $(\Delta \mathrm{R} 2=0.024$,
$\mathrm{F}=4.343, \mathrm{df}=2, \mathrm{p}=0.014)$. Model 2 also exposed a significant impact of Market Orientation on New Product development Ability $(\beta=0.154, p<0.05)$ and a significant impact of Learning Orientation on New Product development Ability $(\beta=0.171, \mathrm{p}<0.05)$. Both results offer support for $\mathrm{H} 1$ and $\mathrm{H} 3$.

Interaction terms also presented significant coefficients. Market Orientation x Innovativeness showed a negative impact on New Product development Ability $(\beta=-0.122$, $\mathrm{p}<0.05)$, while Learning Orientation $x$ Innovativeness exposed a positive effect on New Product development Ability $(\beta=0.187, \mathrm{p}<0.01)$. That supports $\mathrm{H} 2$ and $\mathrm{H} 4$, respectively. Hence, among the firms with low levels of Innovativeness, there was a stronger influence of Market Orientation on New Product development Ability. Among the firms with high levels of Innovativeness, there was a stronger influence of Learning Orientation on New Product development Ability. We also verified the impact of Market Orientation and Learning Orientation on New Product development Ability for groups of firms with low and high levels of Innovativeness separately. For that matter, we divided the sample using the median of Innovativeness - cell sizes for the subgroups were 135 (low Innovativeness) and 150 (high Innovativeness) - and then estimated the regression coefficient of Learning Orientation and Market Orientation on New Product Development Ability (control variables were also included). In the low Innovativeness group, the effect of Market Orientation on MPDA was positive and significant $(\beta=0.349, p<0.01)$, while the impact of Learning Orientation on New Product Development Ability was not significant $(\beta=0.019, \mathrm{p}>0.05)$. On the

Table 3 - Path coefficients of the structural model

\begin{tabular}{|c|c|c|c|c|}
\hline \multirow[t]{2}{*}{ Path } & \multicolumn{2}{|c|}{ Model 1} & \multicolumn{2}{|c|}{ Model 2} \\
\hline & $\begin{array}{c}\text { STD } \\
\text { Coefficient }\end{array}$ & t value & $\begin{array}{c}\text { STD } \\
\text { Coefficient }\end{array}$ & t value \\
\hline \multicolumn{5}{|l|}{ Main Effects } \\
\hline H1: Market Orientation $\rightarrow$ New Product development Ability & $0.151 *$ & 2.367 & $0.154 *$ & 2.435 \\
\hline H3: Learning Orientation $\rightarrow$ New Product development Ability & $0.131 *$ & 1.961 & $0.171 *$ & 2.488 \\
\hline Innovativeness $\rightarrow$ New Product development Ability & $0.301 * *$ & 5.095 & $0.300 * *$ & 5.097 \\
\hline \multicolumn{5}{|l|}{ Moderating Effects } \\
\hline $\begin{array}{c}\text { H2: Market Orientation x Innovativeness } \rightarrow \text { New Product } \\
\text { development Ability }\end{array}$ & & & $-0.122 *$ & -1.963 \\
\hline $\begin{array}{c}\text { H4: Learning Orientation x Innovativeness } \rightarrow \text { New Product } \\
\text { development Ability }\end{array}$ & & & $0.187 * *$ & 2.886 \\
\hline \multicolumn{5}{|l|}{ Control Variables } \\
\hline Competition for sales is intense & -0.001 & -0.021 & -0.008 & -0.146 \\
\hline Technological change in this industry & -0.039 & -0.717 & -0.056 & -1.042 \\
\hline $\mathrm{R}^{2}$ Change & $0.213 * *$ & & $0.024 * *$ & \\
\hline F Value & 15.053 & & 4.343 & \\
\hline $\mathrm{R}^{2}$ & $0.213^{* *}$ & & $0.237 *$ & \\
\hline F Value & 15.053 & & 12.251 & \\
\hline
\end{tabular}


other hand, Market Orientation yielded no significant impact on New Product development Ability $(\beta=0.018$, $\mathrm{p}>0.05)$ and Learning Orientation presented a strong effect on New Product development Ability $(\beta=0.308$, $\mathrm{p}<0.01)$ in the group with high Innovativeness firms.

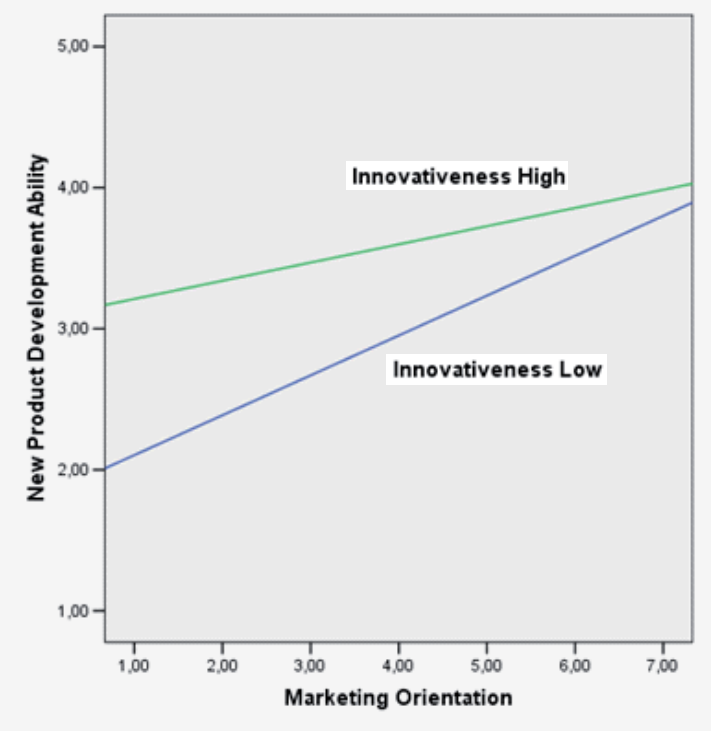

Figure 1 depicts the relationship between Market Orientation and New Product development Ability, besides the relationship between Learning Orientation and New Product development Ability, both with the moderating action of innovation.

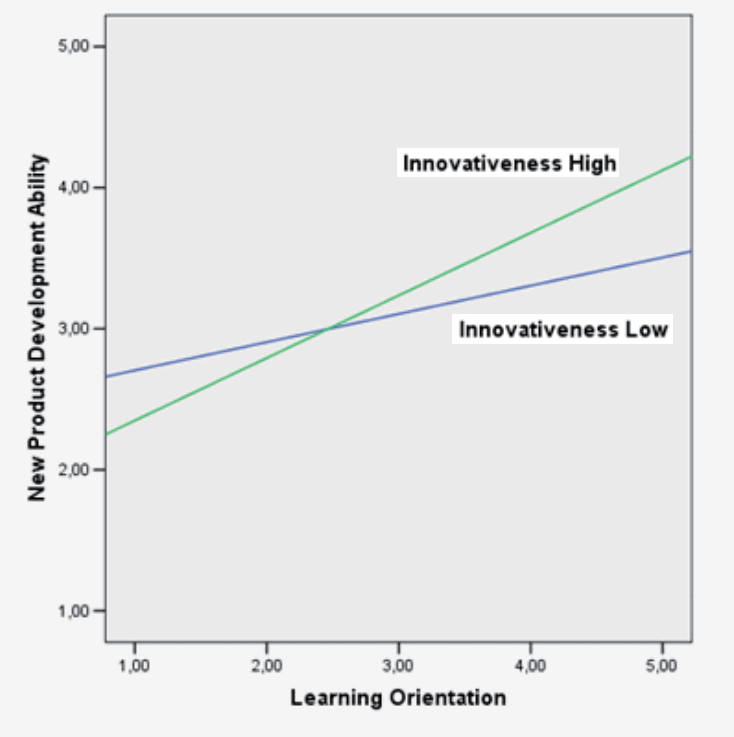

Figure 1-Graphical Presentations of the Interactions

\section{Conclusions and managerial implications}

The marketing literature has dealt with organizational learning closely linked to the Market Orientation construct (Day, 1994; Sinkula, 1994; Slater and Narver, 1995; Dickson, 1996; Sinkula, Baker and Noordewier, 1997; Hurley and Hult, 1998; Baker and Sinkula, 1999). Slater and Narver (1995:67) state that "market orientation is by heritage a learning orientation". Dickson (1996) argues that only learning enables firms to maintain a competitive advantage in the long term through continuous processing of market information at a speed greater than that of competitors. Baker and Sinkula (1999) argue that there is a synergy effect of Learning Orientation and Market Orientation on business performance. To Hurley and Hult (1998) there is a relationship between Learning Orientation and Market Orientation and those with innovation. Farrell (2000) discusses the development of the learning organization oriented towards the market.

From a Market Orientation perspective, the theoretical framework of organizational learning can be seen as an important source of concepts for its implementation, especially considering the ability to learn faster than competitors as the only sustainable competitive advantage (Wei and Atuahene-Gima, 2009). In the context of Market Orientation, Learning Orientation is valuable to the organization, since it encourages the focus on understanding and meeting customer's needs (not only the expressed but also the latent) through new product offerings and services. Hence, Learning Orientation promotes new ways of working in the business (Baker and Sinkula, 2007). This condition leads the firm to better outcomes such as the success of new products, customer retention, superior growth and profitability (Rhee et al., 2010).

The marketing literature suggests commonalities and differences on how constructs affect Learning Orientation and Market Orientation in relation to the ability to successfully develop new products. The findings in this study reinforce some of these similarities and differences. In terms of similarity, there is a significant volume of theory suggesting that the constructs of Learning Orientation and Market Orientation focus on how to acquire knowledge about the market and use it to achieve higher levels of performance (Baker and Sinkula, 2005 and 2007), supporting the importance of constructs to the success of new products (AtuahemeGima, 1996; Lukas and Ferrel, 2000; Farrell, 2000; Rhee et al., 2010). Support for hypotheses H1 and H3 in this study are aligned with this theoretical view. Hence, companies aimed at developing new products need to have market-oriented behaviours in order to generate, disseminate and respond to market information (Kohli and Jaworski, 1990). It facilitates the connection with current and potential customers and helps understanding the competitive dynamics of the market, a basic requirement when launching new products. Similarly, 
companies engaged in processes of organizational learning usually develop a culture of understanding and discussing the up-to-date theories. Organizational members are therefore constantly encouraged to discuss and challenge the norms that guide the processing, the use of market information and the actions of the firm, which lately encourages innovation.

In terms of differences, several studies indicate that the importance of Learning Orientation and Market Orientation for new products success is somehow dependent and moderated by factors such as competitive intensity and market turbulence, but also by the Innovativeness context (Lukas and Ferrell, 2000; Mavondo et al., 2005; Menguc and Auh, 2006; Wei and Atuahene-Gima, 2009; Augusto and Coelho, 2009). Aligned with these authors, our hypotheses $\mathrm{H} 2$ and $\mathrm{H} 4$ help to understand different contexts that would encourage one or another construct (i.e., either Market Orientation or Learning Orientation) in the New Product development Ability. While Market Orientation emphasises knowledge on actual markets, Learning Orientation promotes a wider knowledge (i.e., not only based on the market). Learning Orientation also promotes "generative learning", whilst Market Orientation provides "adaptive learning" (Baker and Sinkula, 2007). Thus, the focus of knowledge acquisition of Market Orientation is based on the market, especially on customers and competitors, while Learning Orientation sources are internally and externally broader.

Further, as depicted in hypothesis H2, a deep knowledge about the market as well as responses aligned with the scope of competitive intelligence is absolutely necessary for the New Product development Ability in low Innovativeness environments. However, in line with our hypothesis H4, in environments where the Innovativeness is high (and innovations tend to occur in a radical way) it is necessary a certain knowledge and culture promoted by Learning Orientation, extrapolating current and latent market knowledge. A new organizational attitude is therefore required, stimulating the development of new skills and driving the firm beyond traditional ways of competition.

Finally, a possible explanation for these results were pointed out by Augusto and Coelho (2009:98): "a firmoriented towards innovation values change, and encourages risk-taking and creativity, making employees feel [...] more likely to be open-minded and think outside the box, generating breakthrough rather than incremental concepts". Hence, firms with a high level of Innovativeness tend to reinforce Learning Orientation in the New Product development Ability process and focus on radical innovation (Sivadas and Dwyer, 2000). In contrast, firms with low level of Innovativeness will prioritize incremental innovations (Baker and Sinkula, 2007) and will drive their New Product Development Ability process towards Market Orientation (Christensen and Bower, 1996; Lukas and Ferrell, 2000).

\section{References}

AIKEN, L. S. and WEST, S. G. (1991). Multiple Regression: Testing and Interpreting Interactions. Newbury Park, CA: Sage Publications.

ARMSTRONG, J. S., and OVERTON, T. S. (1977). Estimating Nonresponse Bias in Mail Surveys. Journal of Marketing Research, 14(3), 396-402.

ATUAHENE-GIMA, K. (1996). Market Orientation and Innovation. Journal of Business Research, 35(2), 93-103.

ATUAHENE-GIMA, K. (2005). Resolving the Capability-Rigidity Paradox in New Product Innovation. Journal of Marketing, 69(4), 61-83.

ATUAHENE-GIMA, K., SLATER, S. F., and OLSON, E. M. (2005). The Contingent Value of Responsive and Proactive Market Orientations for New Product Program Performance. Journal of Product Innovation Management, 22(6), 464-482

AUGuSTO, M., and COELHO, F. (2009). Market orientation and new-to-the-world products: Exploring the moderating effects of innovativeness, competitive strength, and environmental forces. Industrial Marketing Management, 38(1), 94-108.

BAKER, J. M., and SINKULA, W. E. (1999). The synergetic effect of Market Orientation and learning orientation on Organizational Performance. Journal of the Academy of Marketing Science, 27(4), 411-27.

BAKER, W. E., and SINKULA, J. M. (2005). Market Orientation and the New Product Paradox. The Journal of Product Innovation Management, 22(6), 483-502.

BAKER, W. E., and SINKULA, J. M. (2007). Does Market Orientation Facilitate Balanced Innovation Programs? An Organizational Learning Perspective. Journal of Product Innovation Management, 24(4), 316-334.

BARNEY, Jay. (1991). Firm Resources and Sustained Competitive Advantage. Journal of Management, 17(1), 99-120.

CALANTONE, R.J., CAVUSGIL, S.T., and ZHAO, Y. (2002). Learning orientation, firm innovation capability, and firm performance, Industrial Marketing Management, 31(6), 515-524. 
CHANDY, R.K. and TELLIS, G.J. (1998). Organizing for radical product innovation: The overlooked role of willingness to cannibalize, Journal of Marketing Research, 35(4), 474-487.

CHRISTENSEN, C. M. and BOWER, J. L. (1996). Customer Power, Strategic Investment, and the Failure of Leading Firms. Strategic Management Journal, 17 (3), 197-218.

CLAYCOMB, C., \& GERMAIN, R. (1997). Organizational Learning and Performance: an Empirical Test. In Proceedings of American Marketing Association Winter Educators' Conference (pp. 94-100). St. Petersburg, FL: AMA.

CROSSAN, M.M., LANE, H.W., and WHITE, R.E. (1999). An organizational learning framework: from intuition to institution. Academy of Management Review, 24, 522-537.

DAY, G. S. (1994). Continuous Learning About Markets. California Management Review, 36(4), 9-31.

DICKSON, P. R. (1996). The static and dynamic mechanics of competition: a comment on Hunt and Morgan's Comparative Advantage Theory. Journal of Marketing, 60(3), 102-106.

DILLON, William R., THOMAS, J. MADDEN, Neil H. Firtle (1994). Marketing Research in a Marketing Environment. St. Louis: Times Mirror.

FARRELL, M. A. (2000). Developing a MarketOriented Learning Organisation. Australian. Journal of Management, 25(2), 201-222.

FORNELL, Claes and LARCKER, David F. (1981). Evaluating Structural Equation Models with Unobservable Variables and Measurement Error. Journal of Marketing Research, 18(1), 39-51.

GOTTELAND, D., and BOULE, J. M. (2006). The market orientation-new product performance relationship: redefining the moderating role of environmental conditions. International Journal of Research in Marketing, 23(2), 171-185.

HAN, J. K., KIM, N., and SRIVASTAVA, R. K. (1998). Market orientation and organizational performance: is innovation a missing link?. Journal of Marketing, 62(4), 30-45.

HOOLEY, G. J., GREENLEY, G.E., FAHY, J. and CADOGAN, J.W. (2001). Market-focused Resources, Competitive Positioning, and Firm Performance. Journal of Marketing Management, 17 (5-6), 503-520.
HOOLEY, G. J.; GREENLEY, G. E., CADOGAN, J. W.; and FAHY, J. (2005). The performance impact of marketing resources. Journal of Business Research, 58(1), 18-36.

HOOLEY, G.J., MÖLLER, K. and BRODERICK, A.J. (1998). Competitive positioning and the resource-based view of the firm. Journal of Strategic Marketing, 6(2), 97-115.

HULLAND, J. (1999). Use of Partial Least Squares (PLS) in Strategic Management Research: A Review of Four Recent Studies. Strategic Management Journal, 20(2), 195-202.

HULT, G.T.M., HURLEY, R.F., and KNIGHT, G.A. (2004). Innovativeness: Its antecedents and impact on business performance, Industrial Marketing Management, 33, 429-438.

HUNT, S. D., and MORGAN, R. M. (1995). The Comparative-Advantage Theory of Competition. Journal of Marketing, 59(2), 1-15.

HURLEY, R. F., \& HULT, G. T. M. (1998). innovation, market orientation, and organizational learning: an integration and empirical examination. Journal of Marketing, 62(3), 42-54.

IYER, G.R., LAPLACA, P.J. and SHARMA, A. (2006). Innovation and new product introductions in emerging markets: Strategic recommendations for the Indian market. Industrial Marketing Management, 35(3), 373-382.

JAWORSKI, Bernard J. and KOHLI, Ajay K. (1993). Market Orientation: Antecedents and Consequences. Journal of Marketing, 57(3), 53-70

KOHLI, A. K., and JAWORSKI, B. J. (1990). Market orientation: the construct, research propositions, and managerial implications. Journal of Marketing, 54(2), $1-18$.

LAFFERTY, B., and HULT, G. T. M. (2001). A synthesis of contemporary market orientation perspectives. European Journal of Marketing, 35(1-2), 92-109.

LUKAS, B. A., and FERRELL, O. C. (2000). The effect of market orientation on product innovation. Journal of the Academy of Market Science, 28(2), 239-247.

MAVONDO, F.T., CHIMHANZI, J., STEWART, J. (2005). Learning orientation and market orientation: relationship with innovation, human resource practices and performance. European Journal of Marketing, 39(11-12), 1235-1263. 
MCGUINNESS, T., and MORGAN, R. E. (2005). The effect of market and learning orientation on strategy dynamics: The contributing effect of organisational change capability. European Journal of Marketing, 39(11-12), 1306-1326.

MENGUC, B., and AUH, S. (2006). Creating a firmlevel dynamic capability through capitalizing on market orientation and innovativeness. Journal of the Academy of Marketing Science, 34(1), 63-73.

MENON, A., BHARADWAJ, S. G., \& HOWELL, R. D. (1996). The Quality and Effectiveness of Marketing Strategy: Effect of Functional and Dysfunctional Conflict in Intraorganizational Relationships. Journal of Academy of Marketing Science, 24(4), 299-313.

NARVER, John C. and SLATER, Stanley F. (1990). The Effect of a Market Orientation on Business Performance. Journal of Marketing, 54(4), 20-35.

NEILL, Stern \& ROSE, Gregory M. (2006). The effect of strategic complexity on marketing strategy and organizational performance. Journal of Business Research, 59(1), 1-10.

NEVIS, E. C.; DIBELLA, A. J.; GOULD, J. M. (1995). Understanding Organizations as Learning Systems. Sloan Management Review, 36(2), 73-85.

PERIN, M. G., and SAMPAIO, C. H. (2003). The relationship between learning orientation and innovation. Revista Eletrônica de Administração, 9(6), 131-148.

PODSAKOFF, P., MACKENZIE, S., LEE, J. Y., and PODSAKOFF, N. (2003). Common method biases in behavioral research: A critical review of the literature and recommended remedies. Journal of Applied Psychology, 88(5), 879-903.

REBELO, T. M., and GOMES, A. D. (2008). Organizational learning and the learning organization: Reviewing evolution for prospecting the future. The Learning Organization, 15(4), 294-308.

RHEE, J., PARK, T., LEE, D. H. (2010). Drivers of innovativeness and performance for innovative SMEs in South Korea: Mediation of learning orientation. Technovation, 30(1), 65-75.

SINKULA, J. M, BAKER, W. E., \& NOORDEWIER, T. (1997). A Framework for Market-Based Organizational Learning: Linking Values, Knowledge and Behavior. Journal of the Academy of Marketing Science, 25(4), 305-318.
SINKULA, J. M. (1994). Market Information Processing and Organizational Learning. Journal of Marketing, 58(1), 35-45.

SIVADAS, E. and DWYER, F.R. (2000). An examination of organizational factors influencing new product success in internal and alliance-based processes. Journal of Marketing, 64(1), 31-49.

SLATER, S. F., \& NARVER, J. C. (1995). Market Orientation and the Learning Organization. Journal of Marketing, 59(3), 63-74.

SLATER, S. F.; NARVER, J. C. (2000). Intelligence Generation and Superior Customer Value. Journal of the Academy of Marketing Science, 28(1), 120-127.

THEOHARAKIS, V., and HOOLEY, G. (2008). Customer orientation and innovativeness: Differing roles in New and Old Europe. International Journal of Research in Marketing, 25(1), 69-79.

VIEIRA, V. A. (2010). Antecedents and Consequences of Market Orientation: a Brazilian Meta-Analysis and an International Mega-Analysis. Brazilian Administration Review, 7(1), 40-58.

WEI, Y., and ATUAHENE-GIMA, K. (2009). The moderating role of reward systems in the relationship between market orientation and new product performance in China. International Journal of Research in Marketing, $26(2), 89-96$.

WEST, M.A., and ANDERSON, N.R. (1996). Innovation in top management team. Journal of Applied Psychology, 81(6), 680-693.

WOODSIDE, A. G. (2004). Firm orientations, innovativeness and business performance: Advancing a systems dynamics view following a comment on Hult, Hurley, and Knight's 2004 study. Industrial Marketing Management, 34(3), 275-279.

ZOU, S., ANDRUS, D., and NORVELL, D. (1997). Standardization of international marketing strategy by firms from a developing country. International Marketing Review, 14(2), 107-123. 
